\title{
For the Sake of Learning
}

\author{
Essays in Honor of Anthony Grafton
}

VOLUME 2

Edited by

Ann Blair

Anja-Silvia Goeing

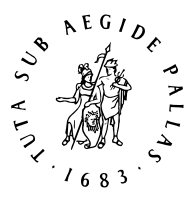

B R I L L

LEIDEN | BOSTON

For use by the Author only | (C) 2016 Koninklijke Brill NV 


\section{Contents}

Editors' Preface XV

List of Figures and Tables XIX

Notes on Contributors XXIV

Anthony Grafton: A Short Biography to 2015 XXXVII

Ann Blair and Nicholas Popper

Anthony Grafton: A Bibliography to 2015 LI

C. Philipp E. Nothaft

\section{Volume 1}

\section{PART 1}

\section{Scaliger and Casaubon}

1 Confidentiality and Publicity in Early Modern Epistolography: Scaliger and Casaubon 3

Dirk van Miert

2 Religion and Politics in the Composition and Reception of Baronius's Annales Ecclesiastici: A New Letter from Paolo Sarpi to Isaac Casaubon 21

Nicholas Hardy

3 Chronology and Hebraism in the World of Joseph Scaliger:

The Case of Arnaud de Pontac (Arnaldus Pontacus) 39

Joanna Weinberg

4 Joseph Scaliger in England

55

Mordechai Feingold

5 What Does an Oriental Scholar Look Like? Some Portraits of Joseph Scaliger and Other Sixteenth-century Oriental Scholars:

A Selection 73

Kasper van Ommen

6 Joseph Scaliger's Treatise De apocryphis Bibliorum (ca. 1591) 91 HenkJan de Jonge 
PART 2

Knowledge Communities

$7 \quad$ Streetwalking and the Sources of Citizen Culture 107 James S. Amelang

$8 \quad$ Baudouin Ronsse as Writer of Medical Letters 123 Nancy Siraisi

9 Performing Humanism: The Andreini Family and the Republic of Letters in Counter-Reformation Italy 140 Sarah Gwyneth Ross

10 A Spanner and His Works: Books, Letters, and Scholarly Communication Networks in Early Modern Europe 157 Daniel Stolzenberg

11 Managing Cardinals' Households for Dummies 173 Laurie Nussdorfer

12 Francis Bacon and the Late Renaissance Politics of Learning 195 Richard Serjeantson

PART 3

Scholarship and Religion

13 Pomponio Leto's Life of Muhammad 215

Margaret Meserve

14 Erasmus, Luther, and the Margins of Biblical Misunderstanding 232 Arnoud Visser

15 When Manuscripts Meet: Editing the Bible in Greek during and after the Council of Trent $\quad 251$

Scott Mandelbrote

16 Theology and the Conditions of Knowledge in the Seventeenth Century: The Case of Discernment of Spirits $\quad 268$

Stuart Clark 
17 John Selden in Germany: Religion and Natural Law from Boecler to Buddeus (1665-1695) 286

Martin Mulsow

18 "Crouch for Employment": Unleashing the Animal Kingdom in the Popish Plot 309

Bruce Janacek

19 Lutheran Islamophiles in Eighteenth-century Germany 327 Alastair Hamilton

20 The Sacrificing King: Ancients, Moderns, and the Politics of Religion 344

Jonathan Sheehan

\section{PART 4}

\section{Cultures of Collecting}

$21 \quad$ Privatbibliotheken antiker Christen $\quad 367$ Roland Kany

22 An Imagined Library in the Italian Renaissance: The Presence of Greek in Angelo Decembrio's De politia literaria 393

Christopher S. Celenza

23 A New World of Books: Hernando Colón and the Biblioteca Colombina 404

William H. Sherman

24 The Rediscovered Third Volume of Conrad Gessner's "Historia plantarum" 415

Urs B. Leu

25 Suchen und Finden vor Google: Zur Metadatenproduktion im 16. Jahrhundert 423

Helmut Zedelmaier

26 The Vatican Library Alphabets, Luca Orfei, and Graphic Media in Sistine Rome 441

PaulNelles 
27 On the Production and Dissemination of a Hebrew Best Seller: Pinhas Hurwitz and His Mystical-scientific Encyclopedia, Sefer Ha-Brit 469 David Ruderman

28 For the Birds: Collecting, Art, and Natural History in Saxony 481 Thomas DaCosta Kaufmann

\section{Volume 2}

\section{PART 5}

Learned Practices

29 Visualisierungen mittels Tabellen $\quad 5^{07}$

Paul Michel

30 Paduan Extracurricular Rhetoric, 1488-1491 542 Anja-Silvia Goeing

31 Cardano's Malicious Horoscope and Gaurico's Morbid Horoscope of Regiomontanus $\quad 561$ N.M. Swerdlow

$3^{2} \quad$ Lingua Adamica and Speculative Philology: Philo to Reuchlin 572 Wilhelm Schmidt-Biggemann

33 Petrarch and Babylon: Censoring and Uncensoring the Rime, 1559-1651 581 Peter Stallybrass

34 Campanella and the Disciplines from Obscurity to Concealment 602 Kristine Louise Haugen

35 Spirits in the Laboratory: Some Helmontian Collaborators of Robert Boyle 621

William R. Newman

36 Cutting and Pasting: Interpreting the Victorian Scrapbook Practices of Sabato Morais 641

Arthur Kiron 


\section{PART 6 \\ Approaches to Antiquity}

37 King Arthur's Merry Adventure in the Vale of Viterbo 661 Ingrid D. Rowland

$3^{8}$ Ancient Texts and Holy Bodies: Humanist Hermeneutics and the Language of Relics 675 Hester Schadee

39 Europe's First Democrat? Cyriac of Ancona and Book 6 of Polybius 692 James Hankins

40 The Early History of Man and the Uses of Diodorus in Renaissance Scholarship: From Annius of Viterbo to Johannes Boemus 711 C. Philipp E. Nothaft

41 Imagining Marcus Aurelius in the Renaissance: Forgery, Fiction, and History in the Creation of the Imperial Ideal $\quad 729$ Thomas Dandelet

42 Marcus Aurelius and the Republic of Letters in Seventeenth-century Antwerp 744 Jill Kraye

43 Stoics, Neoplatonists, Atheists, Politicians: Sources and Uses of Early Modern Jesuit Natural Theology $\quad 761$ Brian W. Ogilvie

44 Henry Savile Reads His Euclid 780 Robert Goulding

45 Natur und Zeit: Antike Motive im Umfeld von Rousseaus Emile 798 Jürgen Oelkers

46 The Whig Interpretation of Homer: F.A. Wolf's Prolegomena ad Homerum in England 821

Diane GrecoJosefowicz 


\section{PART 7}

Uses of Historiography

47 Quae vires verbo quod est "classicum" aliis locis aliisque temporibus subiectae sint quantumque sint eius sensus temporum diuturnitate mutati 845

Salvatore Settis

48 History and Antiquity at French Pilgrim Shrines: Three Pyrenean

Examples 854

Virginia Reinburg

49 Inventing the Middle Ages: An Early Modern Forger Hiding in Plain Sight 871

Paula Findlen

5o Goethe and the End of Antiquarianism 897

Peter N. Miller

$51 \quad$ Georg Ebers, Sympathetic Egyptologist 917

Suzanne Marchand

52 The Rise and Fall of Quellenforschung 933

Glenn W. Most

53 Authenticity, Autopsia, and Theodor Mommsen's Corpus

Inscriptionum Latinarum 955

Lorraine Daston

54 Time Offline and On 974

Daniel Rosenberg

\section{Epilogue}

55 "Studied for Action" Revisited 999

Lisa Jardine

$5^{6}$ The Grafton Method, or the Science of Tradition 1018

Jacob Soll

Index 1033 


\title{
Campanella and the Disciplines from Obscurity to Concealment
}

\author{
Kristine Louise Haugen
}

Two enormous facts define Tommaso Campanella's career. First, he spent twenty-seven years in a Neapolitan prison following a political conspiracy that would have driven the king of Spain from Calabria. But after his release in 1626, Campanella enjoyed an astonishing reversal of fortune, first performing astral magic in Rome with Pope Urban VIII, then publishing a long string of works in Paris, where he had arrived on good terms with the king of France. ${ }^{1}$ Second, Campanella wrote a vast number of books in all fields, the bulk of them while he was imprisoned. Often, his apparent aim was to extirpate Aristotle comprehensively and replace him with a heady new science. But he also composed political tracts, apocalyptic prophecy, poems, and, his most famous work today, a utopia called the City of the Sun, a theocentric and egalitarian republic where there are no prisons. ${ }^{2}$ Campanella achieved European celebrity, and today distinguished scholars make continuous new discoveries about his biography and writings. ${ }^{3}$

The force of Campanella's personality is so implacable that we might forget the obvious. How could he produce this torrent of paper, including relatively

1 On the broader climate of unrest in Naples, see Rosario Villari, Un sogno di libertà. Napoli nel declino di un impero 1585-1648 (Milan: Mondadori, 2012), 27-66. Urban viII: D.P. Walker, Spiritual \& Demonic Magic from Ficino to Campanella (University Park: Pennsylvania State University Press, 2000), 206-9.

2 Tommaso Campanella, La città del sole. Testo italiano e testo latino, ed. Norberto Bobbio (Torino: Einaudi, 1941); Campanella, La Città del Sole: Dialogo Poetico/The City of the Sun: A Poetical Dialogue, trans. Daniel J. Donno (Berkeley: University of California Press, 1981).

3 Any study of Campanella's career must be founded on Luigi Amabile, Fra Tommaso Campanella. La sua congiura, i suoi processi e la sua pazzia, 3 vols. (Naples, 1882), and Fra Tommaso Campanella ne' Castelli di Napoli, in Roma ed in Parigi, 2 vols. (Naples, 1887); and Luigi Firpo's Bibliografia degli scritti di Tommaso Campanella (Torino: V. Bona, 1940), in which conjecture must be distinguished carefully from information. For current studies, see the invaluable Germana Ernst, Tommaso Campanella: The Book and the Body of Nature, trans. David L. Marshall (Dordrecht: Springer, 2010); John M. Headley, Tommaso Campanella and the Transformation of the World (Princeton, NJ: Princeton University Press, 1997); and the journal Bruniana \& campanelliana, in publication since 1995 . 
technical works, while confined to a prison? Like many other early modern prisoners, Campanella had books, paper, and visitors, and he passed his manuscripts outside for circulation and printing. ${ }^{4}$ Sometimes we know the details of these stories; sometimes only his publications hold the traces. Early in Campanella's imprisonment, so his cellmate testified in 1606, a woman who was also his lover delivered astrological books and manuscripts on a rope: an ephemerides, an almanac, and "Cardano." 5 The books he composed, like the Sense in Things, the Atheism Defeated, and the Defense of Galileo, were studded with patristic, scholastic, and classical references, most reliably to the great Dominican Aquinas but also to more recondite sources like Marcus Terentius Varro and Hermes Trismegistus. ${ }^{6}$ Campanella gave lectures in "all sciences" to visitors, and he sent lists of his works to popes and cardinals appealing for his release. ${ }^{7}$ Above all, Campanella gave books to Gaspar Schoppe and Tobias Adami to be circulated outside the prison; Adami printed a series of these in Frankfurt, confirming Campanella's international fame. ${ }^{8}$

Still, there were books and books. Campanella's prison library can never have resembled the libraries of the monasteries where he spent the 158 os and 1590 as a young Dominican, often in penitential confinement. And during his trials from 1599 to 1602 , he was deprived of books altogether, apparently a searing experience. He reported that he wrote at least three works during this time without books: seven books of philosophical poems, 150 political Aphorisms in Italian, and a few pages on earthly kingdoms and the end of the world that he later expanded into the arresting Prophetic Articles. ${ }^{9}$ This situation held no

4 For two prisoners from England, see Nicholas Popper, Walter Ralegh's History of the World and the Historical Culture of the Late Renaissance (Chicago: University of Chicago Press, 2012); and Kristine Louise Haugen, "Thomas Lydiat's Scholarship in Prison: Discovery and Disaster in the Seventeenth Century," Bodleian Library Record 25 (2012): 183-216.

5 Amabile, Congiura, 3:589.

6 Varro and Trismegistus: Campanella, L'Ateismo trionfato, ed. Germana Ernst, 2 vols. (Pisa: Scuola Normale Superiore, 2004), 1:44, 45. Further: Campanella, Del senso delle cose e della magia, ed. Germana Ernst (Bari: Laterza, 2007); Campanella, De sensu rerum, et magia (Paris, 1637); Campanella, Apologia pro Galileo, ed. Michel-Pierre Lerner, It. trans. Germana Ernst (Pisa: Scuola Normale Superiore, 2006); Campanella, A Defense of Galileo, the Mathematician from Florence, trans. Richard J. Blackwell (Notre Dame, IN: University of Notre Dame Press, 1994).

7 Lectures: Campanella to Francesco Barberini, Rome, 21 Feb. 1627, in Campanella's Lettere, ed. Germana Ernst (Florence: Olschki, 2010), 293, no. 72. Popes: Lettere, passim.

8 Collected in Campanella's Opera latine Francofurti impressa annis 1617-1630, ed. Luigi Firpo, 2 vols. (Torino: Bottega d'Erasmo, 1975).

9 Campanella, Sintagma dei miei libri e sul corretto metodo di apprendere, ed. Germana Ernst (Pisa: Fabrizio Serra, 2007), 42-46. See Campanella, Aforismi politici, ed. Antimo Cesaro 
romance for Campanella. At the end of his prophetic arguments, he demanded, "Give me books and I will demonstrate everything visibly and cite passages, and I will prove my expositions from Theology. I declare that the proceedings are invalid if I am not given books." ${ }^{10}$ Campanella's earlier writings had been voluminous and digressive, but now, out of necessity, he was fiery, concise, and clear.11

The story told here is a story about Campanella's ways of speaking. Because he was a seventeenth-century Dominican, that is also a story about his relation to his books. In his earliest works, before the imprisonment in Naples, Campanella was a bibliomaniac who staggered beneath the weight of his citations; as he demolished opponents word by word, he sometimes forgot to say what he thought. But during his long imprisonment, after his time in the bookless dungeon, he discovered two very different styles of argument. First, he learned to speak boldly in his own right, organizing his arguments into small, easy pieces and relegating both opponents and authorities to the margins. We will see this transformation in his works on natural philosophy and poetics before and after his imprisonment.

Second, Campanella's new confidence seems to have carried him a step further for the special purpose of writing about politics. In the texts he published to surround and defend the Latin City of the Sun, his method was concealment, deploying the same techniques of quotation, logic, and debate that had earlier escaped his control. There was a decided purpose. Where his utopia in Latin presented a flagrantly counterfactual world while assimilating it to the surprising model of republican Rome, Campanella's Latin Politics and political Questions proceeded to the negative case against contemporary reality. The Questions' misrepresentations of Aristotle, blatant contradictions, reminders of Campanella's biography, and suspiciously alluring statements of the enemy's position all point to a consistent and simple attack on the legitimacy of kings and their methods. Decades ago, Leo Strauss spoke of philosophers in repressive societies who obscured indiscreet meanings by these and other

(Naples: Alfredo Guida, 1997), which circulated in manuscript; Campanella, Politica in Aphorismos digesta, in Philosophiae realis libri quatuor (Paris, 1637), 4th pagination, 113-44, earlier published in Realis philosophiae epilogisticae partes quatuor (Frankfurt, 1623), 367-414; Campanella, Articuli prophetales, ed. Germana Ernst (Florence: La Nuova Italia, 1977); and for the early document, Amabile, Congiura, 3:489-98.

10 Amabile, Congiura, 3:498: "Dentur libri, et omnia demonstrabo ad oculum, et citabo loca, et monstrabo expositiones meas ex Theolog. ${ }^{\mathrm{a}}$-Protestor de nullitate actorum si non dentur libri."

11 Campanella had books by 1603 or 1604: Amabile, Congiura, 3:589, 2:361. 
techniques, to be excavated laboriously by the most attentive readers. ${ }^{12}$ And in the nineteenth century, Campanella's great biographer Luigi Amabile wrote vividly about disguise and attentive reading in the Questions and the City of the Sun. ${ }^{13}$ If we apply care and circumspection to the Politics and Questions, first published in 1637, they confirm that the corollary to Campanella's ideal republic was the demolition of kingship and economic inequality, an aggressive line that gives a large new dimension to the important question of his engagement with Niccolò Machiavelli. ${ }^{14}$ Under these circumstances, Campanella's lifelong attacks on the political methods of The Prince seem like only the beginning of a far more sweeping program.

It might appear outmoded to open Campanella's seventeenth-century printed books, especially in Latin. For the last four decades, the world has been galvanized by new editions of Campanella's manuscript writings, led by the brilliant Germana Ernst, discoveries that may have seemed to curtail the interest of his printed publications. These editions have called attention to a younger Campanella, typically writing in Italian rather than Latin, and sometimes saying things crucially different from what we knew before. ${ }^{15}$ Yet Campanella authorized every printing during his lifetime, and his European celebrity was largely owing to his aggressive use of the press and of Latin; these publications were anything but unintended. It has also been a traditional and highly demanding challenge to explain Campanella's theology and philosophy in a cohesive way, and above all to determine whether his beliefs changed. ${ }^{16}$ But

12 On methods of "writing between the lines": Leo Strauss, Persecution and the Art of Writing (Chicago: University of Chicago Press, 1988), 24-26, 29-32; also Strauss's Thoughts on Machiavelli (Chicago: University of Chicago Press, 1958), 36.

13 Amabile, Congiura, 2:390.

14 For arguments that Campanella was attracted to elements of Machiavelli's thought, see, e.g., Vittorio Frajese, Profezia e machiavellismo. Il giovane Campanella (Rome: Carocci, 2002); Luca Addante, "Campanella e Machiavelli: indagine su un caso di dissimulazione," Studi storici 45 (2004): 727-50; and Marta De Conti, "Progetto, modello, e messaggio rivoluzionario. L'opera di Tommaso Campanella tra Utopia e Realismo," Rivista di scienze della comunicazione e di argomentazione giuridica 5 (2013): 84-102. For views of Campanella as fundamentally anti-Machiavellian, see the further literature cited in Ernst, Tommaso Campanella, 59n.33.

15 For example, Campanella, Articuli prophetales; Monarchie d'Espagne et Monarchie de France, ed. Germana Ernst (Paris: Presses Universitaires de France, 1997); Campanella, L'Ateismo trionfato; Campanella, Senso delle cose.

16 For discussion: Luca Addante, "Campanella e l'Ateismo trionfato: du paradigme au texte original," Les Dossiers du Grihl, Les dossiers de Jean-Pierre Cavaillé, Libertinage, athéisme, irréligion. Essais et bibliographie, online since 29 Jan. 2008, http://dossiersgrihl.revues. org/2112, accessed 24 July 2014. 
Campanella strove to establish an intellectual career that could not be predicted or pinned down - necessarily, because he aimed to supersede Aristotle's authority in nearly the entire universe of knowledge. ${ }^{17}$ This is one reason why a new direction is added when we ask about Campanella's methods of argument, when we distinguish between the myriad disciplines in which he published, and when we investigate these over time. On the one hand, he was a singular prisoner and prophet; on the other hand, he was an early modern intellectual who shared techniques, methods, and aspirations with many others.

\section{From Bibliomania to Authority: Science and Poetry}

One reason why Campanella repeated himself may have been that as time passed he thought he could do better. He certainly did do better. Among the many works he produced before his Neapolitan imprisonment, two stand out because we can see especially easily how they were later transformed. His Philosophy Demonstrated by the Senses was printed in 1591; its subject was nature, including the soul, but its singular feature was its crushing masses of quotations seemingly designed to defeat an opponent rather than enlighten readers. ${ }^{18}$ Campanella aimed to defend the philosophy of Bernardino Telesio against an attack by the Aristotelian Giacomo Antonio Marta, which he did by unraveling Marta's book word by word and simultaneously canvassing the opinions of philosophers who were wrong, potentially useful, or simply curious. This, of course, was the method of Aristotle or a conventional commentary. But Campanella's desire to display a broad expertise rarely rose to the level of a claim, while it also competed dangerously with the job of demolishing his adversary. He had not yet seen how to turn his bibliomania into an engine of philosophical destruction. ${ }^{19}$

The less prepossessing Italian Poetics was also written with books at hand between Campanella's imprisonments during his vexed career as a young Dominican. He composed this book in 1596 and addressed it to the literary

17 For comparatively wide-ranging discussion of Campanella and Aristotle, see Headley, Tommaso Campanella, 145-79; on natural philosophy, Michel-Pierre Lerner, "Campanella, juge d'Aristote," in Platon et Aristote à la Renaissance, Centre d'Études Supérieures de la Renaissance (Paris: Vrin, 1976), 335-57.

18 Campanella, Philosophia sensibus demonstrata, ed. Luigi De Franco (Naples: Vivarium, 1992); on its bookishness, Ernst, Tommaso Campanella, 8-9; and Headley, Tommaso Campanella, 18, noting misrepresentations in Campanella's accounts of his sources.

19 For a penetrating account of Campanella's approach, see Lerner, "Campanella, juge d'Aristote," 337-42. 
cardinal Cinzio Aldobrandini, thus avoiding philosophical controversy and also invading the world of intellectual fashion. ${ }^{20}$ Campanella began with a visible and simple argument - that poetry must teach morality, an idea undergirded by a theory of "conservation" drawn from Telesio's science of nature. But his exposition devolved rapidly into a descriptive taxonomy: the qualities of the epic hero, ways to subordinate episodes to the main plot, and more. And Campanella nearly always assembled these lists from the same narrow range of works: Virgil, Dante Alighieri, Ludovico Ariosto, and Torquato Tasso. On the whole, no strong impression arises that he cracked the spines of any books. So the Italian Poetics shows a moment not of struggle with authorities, but of a seeming belief that prestige was won through naked information.

After 160o, when Campanella had entered the Neapolitan prison and later regained access to books, he wrote a series of profoundly different works. Suddenly, he apparently cared whether his audiences believed him-and cared whether his audiences understood. The early modern prison was highly permeable to visitors and a space of sociability in its own right, making it seem likely that Campanella freed himself from his books in order to communicate, not only to express himself. The Atheism Defeated and Apology for Galileo show this new approach, dispatching one subject at a time and showing the connection of each idea to a single great argument. ${ }^{21}$ The change is seen even more graphically in Campanella's new book on science and the cosmos, On the Sense of Things and on Magic, finished by 1607 , and in a pyrotechnic Latin Poetics printed in Paris in $1638 .{ }^{22}$ Slowly and clearly, Campanella pressed exactly one point at a time, and he deployed his few quotations only for real support. He also made the revolutionary innovation of dividing his books into short chapters, each devoted to a single claim. Campanella had now become a persuasive force who could go beyond harassing Aristotle's frontiers and seek to replace him wholesale.

Many contemporaries evidently appreciated the subversive science of the Sense of Things, which attributed sensation to trees and stones and castigated

20 Campanella, Poetica, in Opere letterarie, ed. Lina Bolzoni (Torino: Unione tipograficoeditrice torinese, 1977), 335-456. On the composition of these works, Ernst, Tommaso Campanella, 7-8, 40; and further on his associates and books when he composed the first, Campanella, Philosophia sensibus demonstrata, 7-9.

21 The Defense of Galileo was composed in 1616; the Ateismo trionfato was sent to Schoppe for printing in 1607 (Amabile, Congiura, 2:400).

22 Campanella, Senso delle cose and Poeticorum liber unus, in Opere letterarie, 457-663. The Senso delle cose was sent to Schoppe for printing in 1607 (Amabile, Congiura, 2:400), and the printed Latin Poetics cites a Jesuit relation published in 1631, showing that the text was at least revised after Campanella's release: Opere letterarie, 510. 
Aristotle point by point. ${ }^{23}$ The surprising number of books Campanella could cite makes us remember that he was befriended by local Dominicans and others, accounting for his continuing and possibly rotating supply of books. ${ }^{24}$ Here, along with short chapters, Campanella was highly economical in citing both authorities and his enemies, who were now Aristotle and Galen. But clearly, with these books in hand, he could have cited very copiously had he chosen to. His newly elegant reasoning implied a creative austerity even under the bibliographic conditions of a prison. While it is hard to know his exact purpose, it seems clear that he was deliberately cultivating a new image of philosophizing with few citations - certainly, his persistent habit was to manage what others saw and thought of him. The effect of his new method was to stress his argumentative brilliance and force while also, perhaps, whispering of a certain deprivation or injustice.

The Latin Poetics, composed in prison, quietly rested on the same theories as before, but Campanella's arguments had changed from a pot of beans to a sumptuous meal. He took leisurely aim at a series of propositions from Aristotle; only after raising suspenseful questions did he introduce his own philosophy as the necessary answer. Now, rather than asserting baldly that the purpose of poetry must be moral teaching, Campanella took the opposite direction, asking: Can pleasure be the purpose of poetry? What is pleasure, a means or an end? Can pleasure be separated from the good? In the crowded universe of Italian poetics, Campanella had fought his way to the level of Francesco Patrizi's 1586 book, full of aggressive, organized, and passionate argument against Aristotle-with the exception that historical erudition and Greek were never in Campanella's line, so that in this tournament he relied on his wits alone. ${ }^{25}$

\section{Beyond Clarity}

So in the cases of science and poetry, the experience of prison showed Campanella how to argue with compelling force, largely because he now made himself the master and not the servant of his authorities. But when it came to

23 For the many surviving manuscripts, Senso delle cose, 1:xxx-xxxi.

24 For Campanella's friends in Naples, see, e.g., Carlo Longo, op, "Fr. Tommaso Campanella e la Congregazione de Propaganda Fide," Archivum fratrum praedicatorum 68 (1998): 347-67; and Giorgio Fulco, "Il fascino del recluso e la sirena carceriera: Campanella, Ottavio Sammarco e Napoli in una scheggia inedita di carteggio (dic. 1614)," Bruniana \& campanelliana 1 (1995): 33-56.

25 Francesco Patrizi da Cherso, Della poetica... La deca disputata (Ferrara, 1586). 
politics, Campanella developed a different voice that revealed itself only through discrepancies, logical faults, and surprises. Clearly, this voice would have been legible to smaller audiences ready to scrutinize his works intensely, either by inclination or on personal advice. There is little evidence about chronology, but we notice that Campanella's clandestine voice reached its most detailed and systematic realization in his Latin publications. So, for example, the Italian City of the Sun (1607 or before) is simply a strange theocracy whose egalitarian population awaits the end of the world; the Latin City of the Sun (1613 or before) conspicuously resembles the Roman Republic. And if the Italian Aphorisms (1603 or before) seem occasionally designed to cause discomfort, their Latin successor, the Politics (1613 or before), seems designed to cause unrelenting alarm. ${ }^{26}$

In fact, many or any of Campanella's expository works might be read with political concealment in mind. ${ }^{27}$ The case study chosen here is the complete set of Latin political writings published in 1637: the City of the Sun, the Politics expanded from the Italian Aphorisms, and the political Questions. While the Latin City of the Sun and Politics exert their subversive effects more or less in discrete bits, like archipelagoes of surprise, the political Questions resemble billowing clouds of mephitic vapor with their unrelenting discordances, misattributions, and autobiographical allusions. We know they were prepared with deliberation, because Campanella wrote in his account of his works that "we have improved" the Questions "and made them more fit for the press" after they were omitted or withheld from the publication of the City of the Sun in $1623 .{ }^{28}$

We need not suppose that every contemporary reader was ensnared by Campanella's indirect devices. Prison had made him a celebrity, and these political publications can be read simply for their aura of spirited intellect and

26 Campanella reported that the Italian Aphorisms were composed without books toward the beginning of his imprisonment: Sintagma, 44. A search of the prisoners' cells in 1601 turned up only prohibited manuscripts (Amabile, Congiura, 2:231-34), but a fellow prisoner reported that by late 1603 or early 1604 Campanella had various books (n. 11 above). The Italian City of the Sun was sent to Gaspar Schoppe in 1607 (Amabile, Congiura, 2:40o); the Philosophia realis, containing the Latin City of the Sun and the Politics, was given to Tobias Adami in person probably in 1612 or 1613. See Luigi Firpo, "Tobia Adami e la fortuna del Campanella in Germania," in Storia e cultura del Mezzogiorno: studi in memoria di Umberto Caldora (Cosenza: Lerici, 1979), 77-118, esp. 86-87, 92-93.

27 The Spanish Monarchy should certainly be examined; in the 1637 Philosophia realis, the ethical Questions appear to attack kingship under the guise of contesting Machiavelli; the economic Questions should also be examined.

28 Campanella, Sintagma, 48: "sed nunc meliores illos [libros] fecimus ac digniores qui praelo tradantur." 
subtlety. But passage after passage also shows how readers willing to draft themselves into an attentive inner circle could enter and sustain a different conversation.

\section{The Latin City of the Sun as a Roman Republic}

There should be no controversy in pointing out that Campanella's utopian city counted as a republic according to ancient and early modern political theory: it was neither an absolute kingship nor an aristocracy. For Aristotle, a "republic" (politeia) was likely the best government in real states, and it mixed oligarchy and democracy, like the Spartans' constitution. Meanwhile, Machiavelli in the Discorsi specifically compared the early Roman Republic to Sparta, although he thought it contained an element of kingship as well as aristocracy and democracy. ${ }^{29}$ But in the Italian City of the Sun, sent out of the prison in 1607, Campanella seems to have cared more about his solar priesthood and communitarian life than any organized political theory. The only such thing comes when the traveler asks whether the city is a monarchy, aristocracy, or "republic." Clearly, the last option means "constitutional government"-for Aristotle, the better form of democracy. ${ }^{30}$ But the host's reply does not clarify much, as he explains only the Solarians' community of goods, which is shared with the guardians in Plato's antidemocratic Republic. In fact, Campanella in Italian referred to his state in all ways; the word republica appears only seven times in the text, many not even referring to the City of the Sun.

However, by the time he wrote his own Latin translation, printed in 1623 , Campanella was announcing the republican or antimonarchical credentials of his state in deafening tones. He used the word Respublica more than four times as often as in the Italian, a total of twenty-nine instances. ${ }^{31}$ This was achieved both by translating words like città, publico, and commune as Respublica and, even more often, by inserting totally new passages about the Solarians' Respublica. For example, where the Italian City of the Sun said that the Solarian

29 Aristotle, Politics 4.8-10; Niccolò Machiavelli, Discorsi sopra la prima deca di Tito Livio, ed. Francesco Bausi, 2 vols. (Rome: Salerno, 2001), 1:26-29 (1.2), a view earlier rejected by Aristotle (Politics 2.6).

30 Campanella, Città del sole (1941), 62. For politeia in the sense of "constitutional government," the form better than democracy, Aristotle, Politics 3.7. Giving the Italian version to Gaspar Schoppe in 1607: Amabile, Congiura, 2:400.

31 This figure is for both the 1637 and 1623 translations; the inserted and translated passages are the same. 
army was ready to attack "any enemy of reason, for such are not worthy of being human," in the Latin translation the same army attacks the enemies of "the Republic and Religion," who are again unworthy of humanity. In other words, the Solarians are not motivated now by a faculty of the mind but violently committed to the right kind of state. More than this, Campanella has ventilated one of his favorite themes: religion (the right religion) is the indispensable foundation for a state (the right state). ${ }^{32}$

Campanella also pushed the Solarians' claims beyond abstract models into the fertile historical ground of ancient Rome. A few Roman customs had already appeared in transmuted form in the Italian City of the Sun, like the spolia opima given to the soldier who killed a tyrant in battle, and Roman military triumphs. But when he converted his book into the language of the Romans themselves, Campanella crammed it with terms from the law and government of the Roman Republic. Once again, he both translated from the Italian and inserted completely new passages. Now the City of the Sun has triumvirs, the three priests ranking below the Sun; ubiquitous magistratus (offiziali); a Roman dictator, the priest charged with war; a retributive lex talionis; and even Roman baths that in Italian had been simply "ancient." 33

It seems likely that Campanella had not thought of this republican line when he composed his book in Italian. Rather, the evocations of Rome seem to have come later, a humanist layer of argument and allusion superimposed on a prophetic utopia. Nonetheless, bearing in mind the argument that early modern republicanism often centered on freedom from oppression, and that the Italian City of the Sun already stressed the iniquity of tyrants, at least one decisive consequence followed from giving the Solarians' city the trappings of ancient Roman political life: however the enigmatic Sun might best be described, he is definitely not a king. ${ }^{34}$ (We recall that he remains in office until a wiser candidate is found.) So even before Campanella supplemented the Latin City of the Sun with the Politics and Questions, its somewhat improvised Roman story was already intertwined with a suspicion of tyrants and monarchs that places Campanella, however surprisingly, in the mainstream of contemporary political thought.

32 Campanella, Civitas solis, in Philosophia realis (1637), 4th pagination, 156: "Nec abstinent a laedendo hostem Reip. \& Religionis, humanitate indignum"; Città del sole (1941), 79.

33 Ibid., 151ff. (triumviri), 147ff. (magistratus), 156 (dictator), 161ff. (lex talionis), 161 (baths); also tribunal, 158.

34 For only one classic argument about republicanism and negative liberty, see Quentin Skinner, The Foundations of Modern Political Thought, 2 vols. (Cambridge: Cambridge University Press, 1978), esp. vol. 1. 


\section{Aphorisms from Italian Expertise to Latin Theory}

Almost no one to my knowledge has suggested an important connection between the Italian City of the Sun and Italian Aphorisms, which shows yet another element of Campanella's later strategy in Latin: interrelated works that depend on the reader's memory and reflection for their full effect. ${ }^{35}$ The 150 Italian Aphorisms are attractive, easy to read, and sometimes daring. Likely they have been valued precisely because they rely on no one else's authority, and because we can hear them as a single and direct voice dispensing an expert mix of theory and information in the style of Machiavelli's Prince. But the Aphorisms contain their share of contradictions, ambiguous words, and repetitions with noteworthy variations. ${ }^{36}$

One repetition seems especially substantial because it emanated from a prison in Naples, which was of course a Spanish holding. Campanella has raised the subject of colonies, and first the reader is told that an official or ruler who "sends out colonies must be slightly less wise (poco meno savio) than the legislator." Seemingly to clarify that this is not really an insult to the colonialist, legislators are immediately defined as men on the order of Moses or Muhammad who found empires with new laws and religions. On the other hand, only four aphorisms later, it seems that an insult actually was made, because now Campanella hastens to erase it - unless, of course, he is denying that any modern-day colonialist can ever reach the standard of a Moses: "Whoever establishes new colonies must be as wise as a second legislator."37 Overtly, the new assertion "as wise" has removed any impression that colonization might be unwise, and retrospectively it may even give the first aphorism a new, innocuous meaning, approximately "hardly less wise." The king of Spain was the spectacular colonizer of Europe, and Campanella often referred in his other writings to Spain's dealings with the New World natives. But clearly, the strategy here consisted of raising startling questions that go away as soon as the reader blinks, so that both Neapolitan readers and Campanella could have absolutely denied any subversive intent.

35 There is brief discussion in De Conti, "Progetto, modello, e messaggio rivoluzionario," 91.

36 For ambiguous words, e.g., the requisite qualities for priests in Aforismi, 66 (no. 8o): "liberali, ma più in sé avari e verso gli altri prodighi; ...verdadieri, ma più presto superstiziosi cioè stretti in ogni puntiglio di verità, che mendaci; fedeli, ma più tenaci che mutabili...." 
To create the Latin Politics, Campanella surrounded the Italian aphorisms with explanation and theory, divided them into sections, sometimes reordered them, and added tranches of new material that can seem either radically beneath his intelligence or deserving of searching attention. In his chapter on religion as the cause of states, Campanella repeated an apocalyptic prediction from an Italian aphorism: all known religions and states would be changed into new forms until at last they reached their natural condition, namely, rule by a priest acting as king along with a senate. At the end, he now added a single sentence: "From whence it is clear that with this end in view the Spanish Monarchy is joining together the world by the consent of God."38 It is possible that in the clumsiest way he meant to say that the Spanish Empire was destined to preside over a pacified globe. But the kings of Spain were not priests; absorbing another monarchy, like England, would not alter its form; and why should Spain remain unchanged when Campanella had specified that all countries would change government and religion? If Campanella had normal powers of logic, we should consider a meaning congruent with his frequent imaginings of the end of the world: Spain was aggregating earthly kingdoms precisely so that they could be destroyed all at once, in other words, hastening its own immolation. There are also two ways to understand a biblical verse that Campanella inserted in this aphorism in italics, although without citation (Proverbs 28:2): "Because of its sins the earth now has many kings." ${ }^{39}$ Benignly, at the end of time there will be only one king; also possibly, kings have been inflicted on the earth like a vicious pestilence, however well deserved.

Such aphorisms in the Politics could become the foundation for complicated and elusive anti-monarchical arguments in the Questions, on the side being opposed or on the side ostensibly being advocated by Campanella. The disputation form let him address just the subjects he wanted to, calibrating his tone between respectability, silence, and occasional discordance. This method was poorly suited to explaining what he thought a good state should be, but it left abundant clues about the iniquity of kings, tyrants, and slavery.

\section{Asked and Answered}

As a young man, Campanella had struggled to wield the techniques of disputation. Now his competence was clear, and the high regimentation of the form

38 Ibid., 70 (no. 92); Campanella, Politica, 133: "unde videtur Hispanorum Monarchia ad hunc finem congregare Mundum nutu Dei."

39 Campanella, Politica, 133: "Nam propter peccata terra nunc multi Principes eius...." 
only called attention to his deviations from it. First, in the traditional style, Campanella presented the objectionable, typically antiroyalist, view of his opponent, subdivided into many numbered parts and subparts; then he countered with his own ostensible views, also conscientiously organized and numbered. Yet strange and troubling opinions emerged like sharp rocks out of a stormy surf, both while Campanella's opponent was speaking and while he was supposed to be defending kings. We can only investigate these conditions by taking seriously our moments of surprise and reflecting on them in detail, just as Ludovico Ariosto's Orlando propped open the mouth of the orc by entering with both his anchor and his boat. Here I present a few passages from the second Question, but all of the Questions that are not direct commentaries on the City of the Sun reward study.

Campanella's second Question purported to attack Aristotle and Machiavelli, but its very title seems calculated to raise discomfort:

Whether it follows from Aristotle's doctrine that all the princes of the world are tyrants, as Machiavelli claims they are, and as Muhammad appointed them to be. Also, whether they are all tyrants correctly speaking. Also, whether according to Aristotle all peoples are slaves and deserve to be treated as slaves. Also, whether this is done rightly and according to nature. ${ }^{40}$

Campanella, of course, would take the side that these ideas were false. But to attribute them to Aristotle's Politics was to render them so impossible that no rational interlocutor would advance them. In that work, Aristotle distinguishes sharply between kings and tyrants; and far from speaking of kings' subjects as slaves, he envisages populations of masters and slaves in every city. So who actually would claim that all kings were tyrants, and why?

The question could only be heightened when Campanella laid out the specific position he meant to demolish. The provocative words were in fact a heady blend of Aristotle on natural slavery and Campanella's own Latin Politics, which, to readers who remembered that work, sharply called in question the idea that Campanella was really on the attack.

40 Campanella, Quaestiones super tertia parte...quae est de politicis, in Philosophia realis (1637), 4th pagination, 87: "Utrum ex doctrina Arist. sequatur, omnes principes mundi esse tyrannos, quemadmodum cupit eos esse Macchiauellus, \& Macometus instituit. \& an vere tyranni sint omnes. \& utrum omnes populi sint serui, \& tanquam serui tractari debent secundum Arist. \& an hoc sit bene, \& secundum naturam." 
To begin with, it's obvious that all Princes are tyrants if you believe Aristotle. For it's obvious from what he says that all mastership (dominium) that's against nature is tyrannical: but according to Aristotle, all mastership in which the Prince does not excel all his subjects in virtue by as much as the male excels the female, and a father his children, and the soul the body, and humans the beasts, is against nature. But therefore it results that no Prince is tyrannical, because he would excel his Subjects in virtue as much as the soul does the body, and humans the beasts. And so he would need to be of a superior species, and therefore they are all tyrants. ${ }^{41}$

Manifestly, the logic was slippery: legitimate princes were no tyrants because they belonged to a superior species, but in fact there were no such princes. But misattribution to Aristotle compounded the effect of this vertiginous reversal. In fact, Campanella was taking Aristotle's infamous doctrine of natural slavery and inflating it into a political proposition, with some help from himself. Aristotle had indeed said in the Politics that some people are suited by nature to be slaves, if they are as inferior to other people as the body is to the soul, as animals are to humans, and as women are to men. ${ }^{42}$ But Aristotle had been speaking about the household and about classes of people in the city, not about kingship and who is fit to take part in government. Not only was Campanella transmuting the entire subject of natural hierarchy to government; he also inverted every proposition to describe the superhuman superiority of the ruler. And as the reader of the full physical volume recognized, Campanella drew this discussion of the superhuman ruler directly from his own Latin Politics, where its implications were manifestly antimonarchical. There, he said that a good king must excel his subjects as though he belonged to a different species, or were an angel, or Christ; otherwise he rules only by chance -in other words, not by nature. ${ }^{43}$

As Campanella continued his case about tyrants, he sheltered again under the mask of Aristotle, casually remarked that all kings must use the methods of

Ibid., 88: "Primo palam est quidem omnes Principes esse tyrannos si Arist. credas. Nam ex dictis patet, omne dominium contra naturam est tyrannicum: at secundum Arist. omne dominium, in quo Princeps non superat virtute vassallos omnes, quantum mas faeminam, \& Pater pueros, \& anima corpus, \& homo bestias, est contra naturam. ergo tyrannicum constat nullum esse Principem, quia Vassallos superet virtute quantum anima corpus, \& homo bestiam. sic enim oporteret superioris esse speciei, ergo omnes sunt tyranni."

42 Aristotle, Politics 1.5.

43 Campanella, Politica, 118 , Sec. 5 . 
tyrants, and ostensibly defended censorship and even prison. ${ }^{44}$ Before he directly quoted Aristotle on the methods of tyrants, Campanella remarked that Aristotle had also recommended these specific devices:

The first is to make the Subjects ignorant by prohibiting schools, and books of deep learning, and persecuting wise men with false accusations on charges of impiety and lese majesty. ${ }^{45}$

Heresy and lese majesty were of course precisely the charges in the trials against Campanella, and we are constantly learning more about the complex censorship of his books. ${ }^{46}$ While Aristotle had indeed spoken of prohibiting education as a way for a tyrant to quell dissent, all the rest here was redolent of the Counter-Reformation, implicating the papacy as well as Spain in the tyranny of princes.

When Campanella turned to demolishing these and other accusations against kings, his first arguments were terse and weak. ${ }^{47}$ He picked up steam when he reached the tyrannical arts, but his defense was curious. On the one hand, he claimed, such arts were scarcely found in Christian kingdoms. On the other hand, conceding something but still sounding orthodox, he argued that tyrannical arts were justified: "Nor does the fact that some books are prohibited mean that anyone intends to keep the populace ignorant, but rather to guard against heresy and evil morals that are often introduced by such books." 48 On still another hand, he went on, now acknowledging dissent and applying to censors a mildly surprising simile: "The censors of new books bark like dogs who don't recognize their master in the night; later they know him and lie still.

44 All kings must use tyrannical methods: Campanella, Quaestiones, 88; cf. Aristotle, Politics 5.10.

45 Campanella, Quaestiones, 88, Sec. 6: "prima [via] est facere Vassallos ignorantes prohibendo scholas, \& libros altae doctrinae, prosequendo calumniis viros sapientes, quasi impios, \& maiestati insidiantes." Aristotle had described executing potential leaders and banning common meals, education, dinner parties, and gatherings of any kind: Politics 5.11.

46 See Germana Ernst, "Tommaso Campanella fra censura e autocensura. Il caso dell'Atheismus triumphatus," in Praedicatores, inquisitores. III, I domenicani e l'inquisizione romana, ed. Carlo Longo (Rome: Istituto Storico Domenicano, 2008), 499-525.

47 Campanella, Quaestiones, 93.

48 Ibid., 94, Sec. 6: "Neque quia libros quosdam prohibent, intendunt efficere populum ignorantem: sed cauere ab haeresi, \& prauis moribus, qui per tales libros saepe introducuntur." 
Atheists and Aretinos will complain. Good men love such confinement."49 The leap from censorship to confinement, indeed prison (custodia), suddenly recalled the longer list of tyrannical persecutions that Campanella had put in Aristotle's mouth before. With that association in place, the suggestion that virtuous men loved to be imprisoned seemed perceptibly wanting as a defense.

Some of Campanella's arguments emerged, like these, from widely disparate hints that the reader must assemble from remembered episodes of disquiet. At other times, a single intervention was enough, for example at the very end of Question 1, article 1, when Campanella abandoned the form of the disputation completely. Not responding to anything in the adversary's case, he spontaneously raised the subject whether a king might be removed from his throne for under-performance. Citing history and patristics, Campanella answered yes. Then, apropos of even less, he continued to the subject of regicide, with an addendum on who is our master and who is our peer:

Note that it is not permissible for a private person to kill a king who has become a tyrant except by a decree of the Senate, as Nero was condemned. But if someone seizes the throne by force or conspiracy, like Catiline or Oliverotto da Fermo, he can be killed in the act by anyone with great justice. In the text on kingship and mastership we spoke confusedly, [meaning to say] that preeminence is called mastership, and therefore we call our elders masters (dominos), although they are our friends. ${ }^{50}$

The putative correction at the end was flagrantly provocative, because in fact Campanella had said clearly above that brothers and friends call each one another "masters" simply to show respect, never mentioning elders-in other words, that in daily life our "masters" are our peers. Also relevant to cashiering a king, in the same passage above he had observed that the power of political masters is limited by the laws. ${ }^{51}$ For the attentive reader, then, what could it mean to remember that our "masters" are our equals in the very next sentence

49 Ibid.: "Reclamant censores librorum nouorum, ut canes non agnoscentes in nocte herum. postea tamen cognito acquiescunt. conqueratur Atheus, \& Aretinus. boni enim viri hanc custodiam amant."

50 Ibid., 75: "Nota quod non licet priuato homini occidere Regem, qui factus est Tyrannus, nisi declaratum a Senatu: damnatumque ut Nero. Sed si quis inuadat regnum vi, aut dolis ut Catilina \& Liuerotus, potest in ipsa inuasione a quocunque occidi iustissime. Nos in textu de Regno, \& dominio confuse locuti sumus, ut dominium dicit praeeminentiam, unde maiores dominos vocamus, quamuis amicos."

$51 \quad$ Ibid., 73, Sec. 1: "nec solum vocantur Domini, sicut mutuo fratres, \& Amicos Dominos vocamus ob reuerentiam, sed etiam ob potestatem illam licet limitatem lege...." 
after Campanella asked whether it is legitimate to kill our masters? He allowed no certain conclusion to be extracted - on the contrary, he denied the very conclusion to which he was actively drawing attention. But his reader could freely choose to think that Campanella did believe the idea of mastership was a pure convention, making it follow that every kingship was an act of "force or conspiracy" that might merit regicide. Such suggestions, so heavily cloaked in what we would call plausible deniability, seem perhaps designed less to persuade the innocent than to reach silent sympathizers who similarly felt forbidden to speak aloud.

Did Campanella's seventeenth-century readers actually study his books in this way? In an age of Tacitean political philosophies of secret motivation, Neostoic philosophies of political survival, and general theories of political dissimulation, the question is serious. ${ }^{52}$ The field is open for research.

\section{Which Machiavelli?}

A generation ago, when great historians viewed Machiavelli by default as a republican, Campanella's familiarity with Machiavelli along with his hostility to princes would have been easily explained..$^{53}$ But today, when fewer than 10 percent of the entries in a Machiavelli bibliography of the last fifteen years deal with republicanism or the Discorsi, the idea needs spelling out. ${ }^{54}$ Machiavelli was the author of a celebrated work on republics, far from a unique political vision because the republic was a living type of state; his precise relation to earlier Italian theorists of republics is a matter for discussion. ${ }^{55}$ In other words, the argument that Campanella couched hermetically, and in destructive form, was the stuff of respectable discussion elsewhere in Italy, especially when

$5^{2}$ On dissimulation, Rosario Villari, Elogio della dissimulazione. La lotta politica nel Seicento (Bari: Laterza, 1987).

53 Naming only the most groundbreaking contributions, see Skinner, Foundations, 1:157-82; and J.G.A. Pocock, The Machiavellian Moment: Florentine Political Thought and the Atlantic Republican Tradition (Princeton, NJ: Princeton University Press, 1975).

54 On the history, William J. Connell, "Repubblicanesimo e Rinascimento (nella storiografia anglofona del secondo Novecento)," Archivio storico italiano 161 (2003): 343-62; see Alessandro Arienzo, "Per una rassegna bibliografica degli studi machiavelliani (20002014)," online since 22 Nov. 2014, https://unina.academia.edu/AlessandroArienzo, accessed 20 Mar. 2015 .

55 Machiavelli, Discorsi; Machiavelli, Discourses on Livy, trans. Harvey C. Mansfield and Nathan Tarcov (Chicago: University of Chicago Press, 1996). 
confined to positive debate over the nature and institutions of the republic itself. Campanella had contemporaries.

Why, then, did he launch spectacular attacks on Machiavelli throughout his life? No doubt they were well received by his ecclesiastical readers, but we should notice that uniformly these attacks centered on the prescriptions for vile behavior found in The Prince. Some contemporary anti-monarchical readers found a solution to the problem about which kind of state Machiavelli actually supported, a problem that likely does not go away because many scholars today choose not to engage it or assert that his career involves no contradiction. These seventeenth-century readers thought that The Prince, in the guise of a manual of advice, had the true purpose of exposing and indicting the behavior of kings. One was the Protestant Alberico Gentili, who defended Machiavelli as a scourge of tyrants in 1585; another was Campanella's own associate Gaspar Schoppe, who argued that when people learned about tyrants' methods, they hated them and refused to subject themselves. ${ }^{56}$ Conceivably, Campanella himself was measuring his language carefully in phrases such as a typical one we find about dissimulation in the Questions: "Machiavelli gives this law." 57

These may not be violent misreadings of Machiavelli. Campanella himself referred directly to the Discorsi for the argument that the people are more just and hold to treaties better than princes do, adding that they believe the laws they hear every day in the temples. In general, as Leo Strauss noted long ago, Machiavelli praised republics in the Discorsi but never praised kingship in The Prince. Strauss also pointed out that the Discorsi distinguish plainly between kings and tyrants, but The Prince does not, opening to a reader like Campanella the inference that their behavior is hardly different. ${ }^{58}$ But above all, Campanella's tireless defense of religion as the foundation of any state, which has often been taken as an indignant reply to The Prince, showed deep agreement with the Machiavelli of the Discorsi. There, Machiavelli declared that the earliest laws of Rome could not have endured without Numa Pompilius, the second king, who established the city's religion. ${ }^{59}$

$5^{6} \quad$ Alberico Gentili, De legationibus (London, 1585), 109-10 (3.9); Gaspar Schoppe, Paedia politices (Milan, 1624), 42-44.

57 Campanella, Questions, 88: "hanc legem etiam Machiauellus dat."

58 Ibid., 92, elaborating on Machiavelli, Discorsi (Discourses), 1.58-59; Strauss, Machiavelli, 25-26. For Strauss's view, see Harvey C. Mansfield, "Strauss on The Prince," Review of Politics 75 (2013): 641-65.

59 Machiavelli, Discorsi (Discourses), 1.11-14. For the context, see Mark Silk, "Numa Pompilius and the Idea of Civil Religion in the West," Journal of the American Academy of Religion 72 (2004): 863-96. 
A republican Machiavelli is one whom Campanella could have taken as seriously as other contemporaries did. But whether Campanella wrote out of a reasoned interpretation of Machiavelli's works-which seems quite possible - or more opportunistically, out of risky and seething political convictions, a vital conclusion is clear. We should not always treat Campanella as a solitary meteor whistling across the seventeenth-century firmament. He shared with others his aspirations, methods, experiments, and passions. Indeed, at precisely the moments when his concerns were joined with others', he may have been at his most daring and provocative. 